\title{
Research on the Construction of Japanese Major at Colleges and Universities in the New Era
}

\author{
Wei Zou \\ School of Foreign Studies, Xi'an University, 710065
}

\begin{abstract}
Keywords: New era; Construction of Japanese major at colleges and universities; Problems; Countermeasures; Research
\end{abstract}

\begin{abstract}
With the deepening of China's foreign reform and opening up and the comprehensive reform of quality education, the construction of professional curriculum system in colleges and universities has also been continuously innovated with the change of the situation. For the construction of Japanese major in the new period, it is also the same. Only by constantly expanding the recruitment scale, clarifying the cultivation objectives and set professional courses and teaching modes according to students' characteristics can it be possible to better promote the improvement of the teaching quality of Japanese majors in order to improve the comprehensive accomplishment of Japanese majors and to better cope with the severe employment situation. At present, there are still many problems in the construction of Japanese majors in the aspects of faculty, curriculum system setting, teaching mode, teaching idea and teaching practice. This paper analyzes the problems existing in the construction of Japanese majors in the new era and puts forward the countermeasures for reference.

With the development of economy and the progress of the society, and influenced by factors such as international situation, the Japanese majors at China's colleges and universities are faced with difficulties in enrollment, employment and teaching practice and other dilemmas in development. How to deal with these dilemmas in the new era and develop scientific training objectives and teaching methods according to the school's reality and changes in the situation is an important issue in front of Japanese teachers. Only my making constant reforms and innovations in the curriculum system construction, teaching means, teaching concepts and construction of teaching staffs for Japanese majors at colleges and universities can we promote the construction of Japanese majors at colleges and universities comprehensively in the new era so as to cultivate more Japanese majors with high quality and skills.
\end{abstract}

\section{New Situation Faced by Japanese Major at Colleges and Universities in the New Era}

As China joins the WTO, its exchanges with other countries are becoming increasingly frequent, which greatly promotes economic development and cultural integration. Japanese majors at colleges and universities are also faced with new development situation and changes in terms of scale of the major, professional talent training objectives and professional course hours, etc., which are specifically shown in:

Expanding scale of Japanese majors. In the beginning, the Japanese major at colleges and universities was set up as a minor language major. With the development of the situation and the increasing enrollment of the school, more and more students choose to major in Japanese, and the Japanese major at colleges and universities gradually become a major language major, playing an increasingly important role in the construction of professional disciplines at colleges and universities. Many colleges and universities especially establish a Department of Japanese so as to further enhance Japanese teaching and research, practice and exploration.

Professional training objectives: pay more attention to the cultivation of practical ability. In the beginning, the Japanese major was set mainly to cultivate students' ability to listen, speak, read and write so as to effectively cope with cultural different and promote language communication. With the changes of the situation, the Japanese major is also reformed from the purely teaching of theories to the comprehensive cultivation objective combining practical teaching and theoretical teaching, especially cultivating students' language communication ability and practical ability as 
well as their daily oral English communication ability, expression ability, application and innovation ability, etc.

Reduced professional course hours. With changes of the college credit reform, Japanese course hours are also gradually reduced accordingly so as to reduce students' academic pressure.

Faced with the various above new changes, the construction of Japanese majors at colleges and universities must be based on the status quo to deepen professional reform. Besides, due to the changes of the international situation and the Sino-Japanese relations, there are fewer and fewer Japanese enterprises in China, adding difficulty to Japanese graduates in getting a job. Therefore, to strengthen the construction of Japanese courses at colleges and universities, it is necessary to fully analyze the current specific problems in order to find an effective solution.

\section{The Current Construction of Japanese Major at Colleges and Universities in the New Era and Existing Problems}

It is difficult to recruit students and the Japanese major is not so attractive for college students. Influenced by the employment situation, many high school graduates tend to choose some popular majors in China, such as international trade, accounting, science and engineering, but few students choose to major in Japanese, and Japanese has always been an unpopular major that many students are forced or swapped to it. Besides, due to the lack of professional Japanese teachers at many colleges and universities, Japanese major has been gradually cancelled or downsized at many colleges and universities, and some colleges and universities regard it as a selective major or second major. College students basically have no foundation in Japanese, so they need to learn it from scratch, which poses big difficulty for them, so many students are not willing to major in Japanese. Besides, as a minor foreign language, the development of Japanese is not long in China with not much investment in it. All these cause that college students are not willing to major in Japanese and most students hold a negative attitude towards Japanese majors.

Teaching staff construction level is low. The Japanese teachers at colleges and universities are at an obvious disadvantageous position in terms of overall quality, R\&D level and the number of teachers. In recent years, with the increasing number of Japanese majors, the demand for teachers is more and more, but the demand for teachers is increasing, but the demand for teachers is becoming more and more important. Many teachers are even non-specialized Japanese teachers, a teacher often bring a lot of classes and many courses, teaching pressure, there is not enough time to carry out scientific research, training, so teaching practice, teaching quality and knowledge The reserve system is not perfect, and many Japanese courses are not only pay attention to Japanese culture teaching, but also cross-learning with other disciplines, which undoubtedly added a great difficulty to Japanese professional teachers, single knowledge structure, lack of teaching practice And so seriously affect the quality of Japanese teachers teaching, resulting in uneven quality of teachers.

There is no effective practice teaching. For Japanese teaching, practice is also very important. Only through enhanced practice can students better use Japanese for exchanges and foreign trade activities, etc. But the current practice of many colleges and universities is not strong, the most important reason is affected by funds, contacts and other efforts, and Japan and the establishment of a smooth platform for exchanges and cooperation, resulting in a lot of Japanese students practice opportunities, many Japanese teachers teaching tasks, schools Not enough favorable conditions, their own teaching tasks and more energy to carry out teaching practice to explore, which are greatly hinder the practice of teaching.

Weak construction of internship base. For colleges and universities, there are internship bases for many majors to better improve students' application ability and the ability to convert knowledge. For Japanese majors, internship is also important. Only practice can test the learning of theoretical knowledge. Schools do not invest much in this, and even if practical teaching is carried out, there is no targeted training objectives and implementation schemes, but students set certain topic and find enterprises for internship and then complete the internship report. This form of teaching can hardly play an effective role of promoting and generate positive effects.

Wide range of employment for the Japanese majors. With the increasing enrollment of colleges 
and universities, the number of graduates is increasing, and Japanese majors are gradually increasing. Many Japanese majors hope to enter the international trade and other companies in big cities, but are not willing to go to areas with tough conditions and small Japanese enterprises, so the Japanese majors have a narrow range of employment, and many students even turn to do administrative work. Only a small number of students find international professional companies related to their own professional ability to practice their Japanese ability, so as to improve the Japanese professional level and comprehensive skills.

It is difficult to promote international teaching model. To strengthen the construction of college Japanese professional, we should follow the international routes, so schools should strengthen the education internationalization, but in the actual execution process, there are a lot of pressure and difficulties, such as teacher structure, low degree of internationalization, educational philosophy and the actual work cannot effectively combined with teaching, students' understanding of education internationalization, scientific research and the low degree of internationalization, Sino-foreign cooperation in running schools project, difficult to promote, have enough money, and so on, all of these make it difficult to advance in the education internationalization mode.

\section{Specific Measures to Enhance the Construction of Japanese Major at Colleges and Universities in the New Era}

Scientifically determine the goal of Japanese language training at colleges and universities. With the continuous development of China 's "One Belt and One Road" project and the deepening of the reform of colleges and universities, the goal of Japanese professional training should be adjusted to a more professional, high - end, compound training objectives change. Japanese language teaching, not only to enable students to have a higher Japanese professional knowledge, but also proficient in a certain or a few professional knowledge, in order to better meet the needs of society. To strengthen the construction of Japanese majors in colleges and universities should change the ideas and ideas in a timely manner, combined with the current national economic and social development trend to reasonably predict the future talent needs and development direction, so as to develop Japanese professional talents training objectives and training programs, to fully cultivate Japanese professionals And the effective combination of market demand, and strive to cultivate more language skills and professional quality with the complex Japanese talents. To fully understand the national education reform on the Japanese language and other small professional requirements, in the specific training objectives set up in addition to Japanese special courses, full and financial, economic, engineering and other courses have a combination of activities in order to cultivate the application of compound talents. In the training objectives can also be carried out on the cultural teaching, so that Japanese students familiar with Japan's history and culture, customs, so as to cultivate language, improve the ability to convert Japanese and other disciplines and language to have better employment.

Strengthen organization and management of Japanese majors. To strengthen the organization and management, on the one hand, the Japanese Language and Literature Institute of the university should set up a special teaching organization team, Japanese teaching, teacher arrangement, teaching and scientific research, and so on, including the task of teachers, teachers' behavior and so on, through the establishment of a series of perfect Rules and regulations, so as to standardize the teaching behavior of teachers and teaching activities, and then guide teachers to better into teaching and research and teaching practice. Serious discipline, improve the overall level of teachers. In this way, teachers can also put forward more suggestions on teaching construction according to the teaching tasks and so on, so as to optimize the allocation of teaching resources and improve the management level of Japanese professional organizations. On the other hand, we will strengthen the inspection and supervision of the construction of Japanese majors. The main contents include: whether we have formulated the professional training plan and the annual target, the problems existing in the current teaching and scientific research work, and find out the timely feedback of the Japanese teaching quality inspection mechanism. In fact, through the student evaluation, teacher self-evaluation and online mutual assessment, etc., scientific development of Japanese teaching 
assessment program, so as to promote the continuous improvement of Japanese teaching level.

Strengthen the construction of teachers, enhance the teaching staffs' overall level and ability。 On the one hand, we should pay attention to the selection and recruitment of Japanese professional teachers, combine the times change and teaching objectives, formulate scientific programs in the selection and recruitment of teachers, and strictly follow the requirements of the Ministry of Education on the teaching evaluation programs of colleges and universities to ensure the allocation of teachers and the proportion of students It is not only to pay attention to the requirements of professional Japanese in the recruitment of teachers, but also to study the practical ability of Japanese teachers, the ability of academic construction and the application ability between other disciplines, etc., focusing on the introduction of domestic and international literature, society, culture and other professional Highly educated high title staff, so as to optimize the structure of teachers. On the other hand, enrich the training model, create a diversified training system and encourage Japanese teachers to actively participate in various training to enhance their own business skills, such as the international training. Carrying out various types of teacher training sessions, seminars and so on can encourage teachers to participate in the school to give some financial support to improve teachers to participate in academic exchanges and Further study of the enthusiasm of Japanese teachers, to learn more advanced teaching theory, teaching methods, to strengthen communication with other Japanese teachers and international exchange of Japanese experts to promote business promotion, is conducive to teaching practice to explore and apply. At the same time, it is necessary to formulate strict evaluation mechanism of reward and punishment for Japanese teachers, to promote teachers to follow the teaching objectives in strict accordance with the teaching objectives, to guide teachers to increase teaching practice, to encourage teachers to participate in teaching and research, to promote the Japanese teachers teaching and research slow to meet the requirements, but also take effective measures to punish, so as to promote teachers to actively carry out teaching practice, teaching and research, to comply with teacher management system.

Perfect Japanese curriculum construction system. First, we must combine the needs and characteristics of the development of the school, the development of complex talents training mode of Japanese professional curriculum syllabus and teaching plan, to fully consider the weak basis of the students in the professional curriculum to the basic teaching, step by step to promote the main Combined with the academic advantages of the school to carry out Japanese teaching and other disciplines between the integration of teaching, so as to enrich the Japanese teaching curriculum system. Second, we should make full use of multimedia, computer networks and other new media means in the teaching classroom to enrich the Japanese teaching resources, improve students' interest and enthusiasm in learning Japanese, and promote good interaction between teachers and students. Third, to the Japanese textbook selection and other strict checks, according to the changes in the situation and the school training objectives and requirements, select the characteristics of students and training objectives of professional Japanese textbooks, pay attention to practicality, timeliness and internationalization, as much as possible to choose Japanese original textbooks, And the current international important Japanese research results into classroom case teaching, so as to improve the international level of teaching.

Speed up the construction of practical teaching bases, broaden the practice and internship channels. First, colleges and universities should develop a scientific organization and implementation of the program and strengthen the supervision of the internship process, so as to ensure effective and orderly practice and improve Japanese majors' practical ability. The second is to strengthen the practice of integration with other disciplines to explore the mode of integration, and form communication platform, the use of other disciplines of internship advantages to strengthen cooperation with related enterprises, so as to provide students with more practical places. With the local Japanese enterprises to strengthen contact and communication, to create a combination of production and teaching outside the school practice base.

Strengthen the construction of teaching reform as well as teaching and research. On one hand, colleges and universities should change the teaching concept, focus on cultivating students 
autonomous learning ability, innovation and practice ability, and attach importance to the students' subjective position and individualized development, and combine the extracurricular time and teaching classroom effectively from the aspects of teaching methods, teaching mode and curriculum system To carry out comprehensive innovation and reform; on the other hand, adjust the curriculum, focusing on training the basic skills of students, humanities in the teaching process, teachers should mobilize students as much as possible to take the initiative to think, to cultivate students' application ability as teaching focus, conduct a comprehensive reform of the student assessment and evaluation methods to avoid the idea of the only score theory; at the same time carefully build the second classroom activities to encourage students to actively participate in the Japanese professional debate debates, speech competitions, clubs and seminars, etc., to create a good Japanese learning environment so as to improve students' enthusiasm for learning Japanese and the level of language communication practice.

Strengthen international exchanges, build more employment service platforms. Colleges and universities should actively cope with teaching reform, fully realize the significance of international cooperation in teaching, explore effective ways to communicate, learn advanced educational concepts, seek suitable development path in cooperative school running and establish more professional and featured Japanese courses according to relevant national policies and development strategy deployment so as to improve the comprehensive quality and professional skills of Japanese majors and promote exchanges and cooperation between China and other countries. In addition, for the narrow range and difficulty of employment for Japanese majors, colleges and universities should actively establish the employment information network platform for Japanese majors to provide various employment demand information timely and enhance connection with enterprises so as to provide more employment opportunities for Japanese graduates.

In short, there are still many problems in the construction of the Japanese major at colleges and universities in the new era. Only by combining the policy requirements, market changes and colleges and universities' reality and through effective exploration and formulation of targeted measures can it be possible to solve problems in teaching, research and employment so as to cultivate and transmit more high-quality and comprehensive Japanese professionals to the society.

\section{References}

[1] Zhang Xiaoning, Bai Chunyang. The Geographical Advantages of Japanese Teaching and the Reform in the New Situation [J]. Journal of Shenyang Normal University (Social Science Edition), 2013, (03):107-109.

[2] Tao Yun. Cultivation of Innovative Talents and Teaching Reform of Japanese Major - On the Future Development of Japanese Majors in Minzu University of China [J]. Ethnic Education Research, 2013, (02): 22-27.

[3] Xiu Gang. Some Reflections on Japanese Major Education at China's Colleges and Universities during the Transitional Period [J]. Japanese Language Learning and Research, 2011, (04): 1-6.

[4] Chen Anli. On the Way to Improve the Curriculum Reform of Japanese Majors from the Implementation of Japanese Specialty Construction and Talent Training Program at Colleges and Universities [J]. Foreign Language Teaching in Shandong Province, 2008, (06): 70-73. 